\title{
Pediatric cancer and Li-Fraumeni/Li-Fraumeni-like syndromes: a review for the pediatrician
}

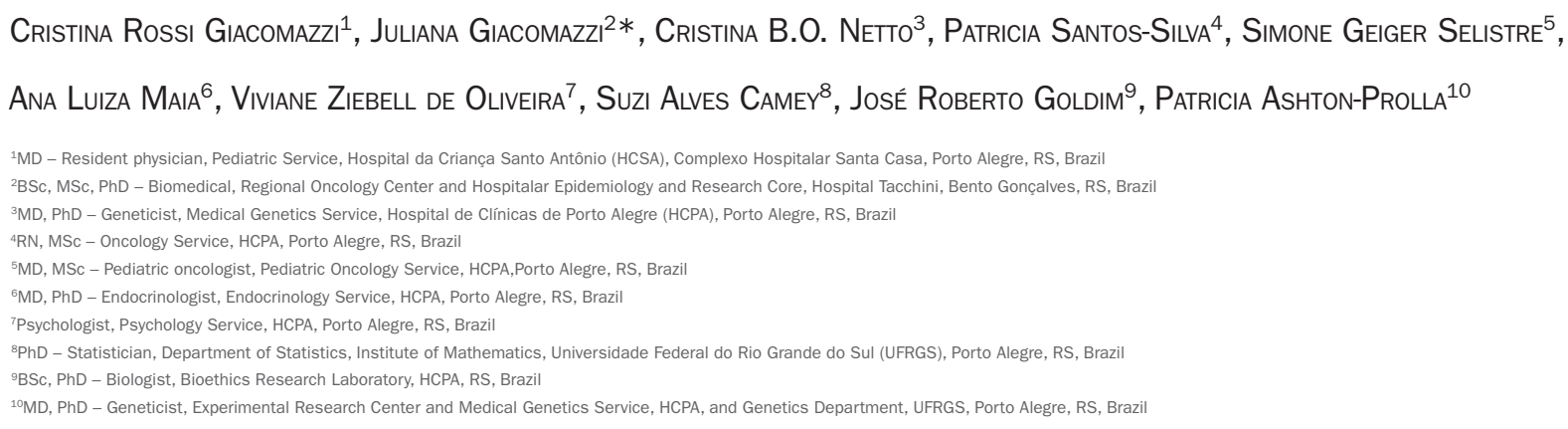

Cristina Rossi Giacomazzi ${ }^{1}$, Juliana Giacomazzi ${ }^{2 *}$, Cristina B.O. Netto ${ }^{3}$, Patricia Santos-Silva ${ }^{4}$, Simone Geiger Selistre ${ }^{5}$, Ana Luiza Maia ${ }^{6}$, Viviane Ziebell de Oliveira ${ }^{7}$, Suzi Alves CameYº, José Roberto Goldim ${ }^{9}$ Patricia Ashton-Prolla ${ }^{10}$

${ }^{1} \mathrm{MD}$ - Resident physician, Pediatric Service, Hospital da Criança Santo Antônio (HCSA), Complexo Hospitalar Santa Casa, Porto Alegre, RS, Brazil 2BSc, MSc, PhD - Biomedical, Regional Oncology Center and Hospitalar Epidemiology and Research Core, Hospital Tacchini, Bento Gonçalves, RS, Brazi ${ }^{3} \mathrm{MD}$, PhD - Geneticist, Medical Genetics Service, Hospital de Clínicas de Porto Alegre (HCPA), Porto Alegre, RS, Brazil

Study conducted at the Hospital de Clínicas de Porto Alegre (HCPA), Porto Alegre, RS, Brazil

Article received: 4/13/2014 Accepted for publication: 10/17/2014

*Correspondence: Address: Rua José Mário Mônaco, 358 Bento Gonçalves, RS - Brazil Postal code: 95700-000 juliana.giacomazzi@tacchini.com.br

\section{SUMmarY}

Introduction: cancer is the second leading cause of death in children between the ages of 0 and 14 years, corresponding to approximately $3 \%$ of all cases diagnosed in Brazil. A significant percentage (5-10\%) of pediatric cancers are associated with hereditary cancer syndromes, including Li-Fraumeni/Li-Fraumeni-like syndromes (LFS/LFL), both of which are caused by TP53 germline mutations. Recent studies have shown that a specific TP53 mutation, known as p.R337H, is present in 1 in 300 newborns in Southern and Southeast Brazil. In addition, a significant percentage of children with LFS/LFL spectrum tumors in the region have a family history compatible with LFS/LFL.

Objective: to review clinical relevant aspects of LFS/LFL by our multidisciplinary team with focus on pediatric cancer.

Methods: the NCBI (PubMed) and SciELO databases were consulted using the keywords Li-Fraumeni syndrome, Li-Fraumeni-like syndrome and pediatric cancer; and all manuscripts published between 1990 and 2014 using these keywords were retrieved and reviewed.

Conclusion: although LFS/LFL is considered a rare disease, it appears to be substantially more common in certain geographic regions. Recognition of population-specific risks for the syndrome is important for adequate management of hereditary cancer patients and families. In Southern and Southeastern Brazil, LFS/ LFL should be considered in the differential diagnosis of children with cancer, especially if within the spectrum of the syndrome. Due to the complexities of these syndromes, a multidisciplinary approach should be sought for the counseling, diagnosis and management of patients and families affected by these disorders. Pediatricians and pediatric oncologists in areas with high prevalence of hereditary cancer syndromes have a central role in the recognition and proper referral of patients and families to genetic cancer risk evaluation and management programs.

Keywords: Li-Fraumeni syndrome, neoplasms, genes, p53, genetic counseling, TP53. 


\section{INTRODUCTION}

Cancer is one of the leading causes of death in children between the ages of 0 and 14 years, second only to trauma. ${ }^{1}$ As compared with adult tumors, pediatric cancers generally exhibit lower latency periods, rapid growth and more aggressive behavior. However, they are more responsive to treatment, and the prognosis is usually good. ${ }^{2-5}$ In Brazil, the National Cancer Institute estimates that approximately 11,300 new cases of cancer have been diagnosed in patients under the age of 19 years in the year 2012, which accounts for approximately $3 \%$ of all malignancies diagnosed in the country. The most common neoplasms in childhood (in Brazil and worldwide) are leukemias, lymphomas, and central nervous system tumors. ${ }^{6}$

A diagnosis of pediatric cancer must prompt the hypothesis of a hereditary cancer predisposition syndrome in the family, particularly if there are concurrent congenital abnormalities or positive family history of cancer. Genetic conditions that may be associated with a higher risk of cancer in childhood include: genodermatoses (i.e. neurofibromatosis type 1 and tuberous sclerosis), overgrowth syndromes (Beckwith-Wiedemann and Proteus syndromes) and adult cancer syndromes which include increased risk to cancer in infancy, childhood and adolescence, such as Li-Fraumeni syndrome (LFS) and its variant - Li-Fraumeni-like syndrome (LFL). ${ }^{7}$

Approximately $5-10 \%$ of all tumors are associated with inherited high-penetrance mutations in cancer predisposition genes. However, an even higher proportion of pediatric cancers may be associated with a familial history suggestive of hereditary cancer. Indeed, in a recent study, conducted by our research group in Southern Brazil, criteria for LFS/LFL were observed in $25 \%$ of a consecutive series of pediatric patients with tumors of the LFS/LFL spectrum. ${ }^{8}$

Several genes associated with cancer predisposition syndromes have been identified in recent years, and specific diagnostic tests have become available. In this new context, pediatricians can expect to be asked more questions on the risks of these genetic syndromes, as well as on management and reduction of cancer risk in affected children. ${ }^{7}$ Therefore, the present article seeks to provide a comprehensive and up-to-date review on Li-Fraumeni/ Li-Fraumeni-like syndromes.

\section{Methods}

The NCBI (PubMed) and SciELO databases were consulted using the keywords Li-Fraumeni syndrome, Li-Fraumeni-like syndrome and pediatric cancer and all manu- scripts published between 1990 and 2014 using these keywords were retrieved and reviewed.

\section{Review}

\section{Li-Fraumeni (LFS) and Li-Fraumeni-like (LFL) syndromes}

Li-Fraumeni syndrome (LFS; OMIM \#151623) is a clinically heterogeneous hereditary cancer predisposition syndrome characterized by an autosomal dominant inheritance pattern, diagnosis of various tumor types at a young age, multiple primary tumors, and a characteristic family clustering pattern of a core spectrum of cancers (core tumors including: bone and soft-tissue sarcomas, central nervous system tumors, leukemia, adrenocortical carcinoma, and breast cancer) ${ }^{9,10}$ LFS is distinct from other hereditary cancer syndromes in that it is associated not with one (or a few) specific type(s) of cancer, but with a broad spectrum of tumors.

Other cancer types have been detected in LFS families and included in some of the diagnostic criteria including bronchioloalveolar carcinoma, prostate cancer, pancreatic cancer, germ cell tumors, and melanoma. ${ }^{11,12}$ The diagnosis of cancer follows a bimodal distribution, with many diagnoses before the age of 10 and a second peak between the ages of 30 and 50 years.

Additional tumor types (ovarian, endometrial, esophageal, gastric, colorectal and thyroid cancer, choroid plexus carcinoma, lymphomas and Wilms' tumor) have been associated to a lesser extend to LFS and also to Li-Fraumeni-like syndrome (LFL), classified according to the Birch, Eeles 1 and Eeles 2, Chompret or modified Chompret criteria. In LFL, average age at cancer diagnosis is older than seen in LFS. Currently used criteria to suggest these diagnoses are summarized in Table 1.

TP53 is the only gene that has been associated with LFS/LFL. ${ }^{13}$ The mean age at diagnosis of cancer in patients with LFS and germline TP53 mutations is 25 years, and the cumulative risk of cancer by the age of 30 is $50 \%$, exceeding $90 \%$ by age $60 .{ }^{14-16}$ The estimated penetrance of cancer in men with mutations in this gene is about $73 \%$. In women, penetrance is complete (100\%), possibly due to the high frequency of breast cancer.

In addition to the broad spectrum of LFS-related tumors, affected individuals are also at risk of developing multiple synchronous or metachronous primary tumors. In a study of 200 patients who had a single primary tumor at the time of enrollment and were recruited from 24 LFS families, 30 (15\%) developed a second primary tumor, 8 (4\%) developed a third primary tumor, and 4 (2\%) developed a fourth primary tumor. ${ }^{17}$ Other studies have shown that the odds of developing multiple primary tumors are 
TABLE 1 Clinical criteria for Li-Fraumeni and Li-Fraumeni-like syndromes.

\section{Clinical criteria \\ Classical LFS \\ (Li, Fraumeni et al., 1988)}

LF - Birch

(Birch, Hartley et al., 1994)

LFL - Eeles 1 (Eeles, 1995)

Eeles 2 (Eeles, 1995)

\section{Description}

I- sarcoma diagnosed in childhood/young adulthood ( $\leq 45$ years) and

II- first-degree relative with any cancer in young adulthood ( $\leq 45$ years) and

III- first- or second-degree relative with any cancer diagnosed in young adulthood ( $\leq 45$ years) or sarcoma diagnosed at any age.

I- childhood cancer (at any age) or sarcoma, CNS tumor, or ACC in young adulthood ( $\leq 45$ years) and

II- first- or second-degree relative with LFS-spectrum cancer (sarcoma, BC, CNS tumor, ACC, leukemia)

at any age and

III- first- or second-degree relative with any cancer diagnosed at age $<60$ years.

I- at least 2 first- or second-degree relatives with LFS-spectrum cancer (sarcoma, BC, CNS tumor, ACC, leukemia, melanoma, prostate cancer, pancreatic cancer) diagnosed at any age

I- sarcoma diagnosed at any age and

II- at least 2 other tumors diagnosed in one or more first- or second-degree relatives: BC at age $<50$ years; CNS tumor, leukemia, ACC, melanoma, prostate cancer, pancreatic cancer at age < 60 years; or sarcoma at any age.

LFL - Chompret

I- diagnosis of sarcoma, CNS tumor, BC, ACC at age < 36 years and

(Frebourg, Abel et al., 2001)

II- first- or second-degree relative with any of the above cancers (except $\mathrm{BC}$ if proband had $\mathrm{BC}$ ) or relative with multiple primary tumors at any age or

III- multiple primary tumors, including two of the following: sarcoma, CNS tumor, BC, or ACC, with the first tumor diagnosed at age $<36$ years regardless of family history; or IV- ACC at any age, regardless of family history.

LFL - Modified Chompret I- index case with LFS-spectrum cancer (sarcoma, BC, CNS tumor, ACC, leukemia, bronchioloalveolar (Bougeard, Sesboüé et al., 2008; Tinat, Bougeard et al., 2009) carcinoma) occurring at age $<46$ years and

II- a first- or second-degree relative with LFS-spectrum cancer occurring at age $<56$ years (except BC if the index case has BC as well), or multiple tumors; or

III- index patient with multiple tumors, at least two of which are in the LFS spectrum, the first occurring at age < 46 years; or

IV- ACC or choroid plexus carcinoma occurring at any age or BC occurring at age < 36 years without $B R C A 1$ or BRCA2 mutations.

ACC: adrenocortical carcinoma; BC: breast cancer; CNS: central nervous system; LFS: Li-Fraumeni syndrome; LFL: Li-Fraumeni-like syndrome.

inversely proportional to age at diagnosis of the first tumor: the relative risk of a second tumor and confidence intervals (CI) were 83 (36.9-87.6), 9.7 (4.9-19.2), and 1.5 (0.5-4.2) for patients originally diagnosed at the ages of $0-19,20-44$, or $\geq 45$ years respectively, and 5.3 (2.8-7.8) when data for all ages were pooled. Decreasing age at diagnosis has been observed in successive generations of carriers, ${ }^{17-19}$ resembling the anticipation (Table 2). It has also been suggested that carriers of germline TP53 mutations are more susceptible to radiation-induced tumors. ${ }^{17,20-22}$

The incidence of LFS/LFL has been estimated at 1:2,000-5,000 in Europe and North America. ${ }^{23,24}$ However, in Brazil, case series of patients from the Southern and Southeastern regions suggest that a particular TP53 germline mutation, p.R337H, occurs at a frequency of 1 in 300 in the general population. ${ }^{25,26}$ It is exceedingly common among children with adrenocortical and choroid plexus tumors (approximate frequencies of 80 and 100\%, respec-
TABLE 2 Risks for second primary tumor in patients with Li-Fraumeni and Li-Fraumeni-like syndromes according to age at diagnosis of the first tumor.

Age at diagnosis of $1^{\text {st }}$ primary Relative risk of a second tumor (years) primary tumor $(95 \% \mathrm{Cl})$

\begin{tabular}{ll}
\hline $0-19$ & $83.0(36.9-87.6)$ \\
\hline $20-44$ & $9.7(4.9-19.2)$ \\
\hline$\geq 45$ & $1.5(0.5-4.2)$ \\
\hline All ages & $5.3(2.8-7.8)$ \\
\hline
\end{tabular}

Source: Hisada et al. ${ }^{25}$

tively), women with breast cancer (frequency around 7\%), being most prevalent in the group diagnosed before 45 years, and among women with phyllodes tumors of the breast (frequency of 5.7\%). ${ }^{27,28}$ Knowing these high rates in Southern and Southeastern Brazilian regions, a strategy is urgently needed to properly identify high risk patients from LFS/LFL families, especially among pediatricians. 


\section{Clinical diagnosis}

Clinical suspicion of LFS/LFL is raised by the diagnosis of tumors strongly associated with these syndromes. Any infant, child or adolescent presenting with adrenocortical carcinoma, choroid plexus carcinoma or anaplastic rhabdomyosarcoma, irrespective of a positive familial history of cancer must be investigated for the possibility of LFS or LFL. ${ }^{29}$ In addition, cancer-affected children with a family history of LFS/LFL-spectrum tumors following certain pattern of ages at diagnosis, degrees of relatedness between cancer-affected relatives (fulfilling clinical criteria for these syndromes) indicates analysis of germline TP53 mutations. ${ }^{10,30-33}$ A definitive diagnosis of LFS/ LFL is established only when a germline TP53 mutation is identified.

\section{Assessment of a suspected LFS/LFL case}

The first step in the assessment of a patient with suspected LFS/LFL should be a thorough analysis of the cancer family history in a pedigree including at least three generations. All reports of cancer in the family should be confirmed by medical records, pathology reports and/or death certificates. In addition to tumor type and site, the age at diagnosis and current age (or age at death) of each affected individual should be recorded. Differential diagnosis may include other hereditary cancer syndromes since some phenotypic features are overlapping among these (i.e. LFS/LFL $v$ s. hereditary breast and ovarian cancer or breast and colon cancer syndrome in families with early onset breast cancer). ${ }^{34}$

\section{Molecular diagnosis}

The TP53 gene is located on chromosome 17 (17p13.1) and spans approximately $20 \mathrm{~Kb}$. It comprises 11 exons that encode $\mathrm{p} 53$, a transcription factor structurally defined by 5 domains. The DNA-binding domain is the site of over $90 \%$ of the somatic mutations observed in sporadic tumors and also of the majority of germline mutations. In Brazilian families fulfilling LFS/LFL criteria, a mutation outside the DNA-binding domain, in exon 10 (which encodes for the oligomerization domain) is the most common alteration. ${ }^{35}$

Clinical criteria for LFS/LFL can be used to estimate the likelihood of germline TP53 mutations. Approximately $70 \%$ of families that meet criteria for classical LFS, 32 and $25 \%$ of those meeting the Chompret criteria (original Chompret and modified Chompret criteria, respectively), $25 \%$ of those meeting the Birch criteria and 14 and $8 \%$ of those meeting the Eeles criteria (Eeles 1 and Eeles 2 criteria, respectively) will carry germline TP53 mutations. ${ }^{36-39}$
The gold-standard method for detection of pathogenic mutations in patients fulfilling LFS/LFL criteria is sequencing of the entire coding region of the TP53 gene. Testing for gene rearrangements (large deletions and duplications) in TP53 should be considered in families whose phenotype elicits a strong clinical suspicion (for example: with multiple early onset tumors) and where sequencing of the coding region did not result in the identification of mutations ${ }^{40}$ supplemental methods, such as MLPA (multiplex ligation-dependent probe amplification), are required for diagnosis of gene rearrangements.

Genetic counseling and management of families with LFS/LFL De novo mutation accounts for approximately $7 \%$ of patients with LFS/LFL-spectrum tumors diagnosed at a young age..$^{41}$ In this setting, siblings will be at a very low risk of the condition, although some risk exists due to the possibility of germline mosaicism for the mutation in one parent. The majority of persons with LFS/LFL, however, have multiple affected relatives, usually across two or more generations. The risk to siblings of a LFS/ LFL mutation carrier will depend on the parental genotype. If either parent is a carrier, the proband's siblings will have a $50 \%$ chance of having also the condition.

Once a TP53 mutation has been identified, the key focus of LFS/LFL management is attempted modification of cancer risk. Carriers of germline TP53 mutations, particularly mutations affecting the DNA-binding domain of p53, have a lifetime risk of cancer that exceeds by far the risks for the general population.

Although LFS/LFL is unquestionably associated with a higher risk of cancer, the potential risks and actual benefits of cancer screening strategies in these patients have not been established definitively. ${ }^{34}$ The core benefits of cancer screening are based on the concept of early detection of tumors. Due to the diverse range of tumors found in the LFS spectrum, a thorough assessment of the cancer family history is essential, as established diagnoses in other family members has been used with caution to guide screening strategies for asymptomatic relatives.

Several cancer screening strategies for patients with LFS/LFL have been published in recent years, including the NCCN guidelines, and excellent management reviews in GeneReviews and Orphanet. In 2011, Villani et al. showed for the first time that a laboratory- and imagingbased screening protocol was able to detect tumors at very early stages in TP53 germline mutation carriers. This strategy had a significant impact on survival rates $(100 \%$ in screened versus $21 \%$ in unscreened patients). ${ }^{42}$ The screening protocol proposed for children involves abdom- 
inal pelvic ultrasound, urinalysis, and blood work every 3-4 months and whole-body and brain MRIs once a year (Table 3). This protocol was designed for subjects with high-penetrance TP53 mutations, such as the DNA-binding domain mutations.

\begin{tabular}{|c|c|}
\hline Tumor type & Screening strategy \\
\hline $\begin{array}{l}\text { Adrenocortical } \\
\text { carcinoma }\end{array}$ & $\begin{array}{l}\text { Abdominal ultrasound every } 4 \text { months } \\
\text { Urinalysis every } 4 \text { months } \\
\beta \text {-hCG, AFP, } 17 \mathrm{OHP} \text {, testosterone, DHEAS, } \\
\text { androstenedione, ESR, LDH every } 4 \text { months }\end{array}$ \\
\hline $\begin{array}{l}\text { Central nervous } \\
\text { system tumors }\end{array}$ & Whole-body MRI once yearly \\
\hline $\begin{array}{l}\text { Bone and soft tissue } \\
\text { sarcomas }\end{array}$ & Whole-body MRI once yearly \\
\hline $\begin{array}{l}\text { Leukemia and } \\
\text { lymphoma }\end{array}$ & Complete blood count every 4 months \\
\hline
\end{tabular}

17OHP: 17-hydroxyprogesterone;

AFP: $\alpha$-fetoprotein;

$\beta$-hCG: beta-human chorionic gonadotropin;

DHEAS: dehydroepiandrosterone sulfate;

ESR: erythrocyte sedimentation rate;

LDH: lactate dehydrogenase;

MRI: magnetic resonance imaging

Source: Villani et al. 2011. ${ }^{40}$

\section{Psychological aspects}

Pre-symptomatic genetic testing of children and adolescents is indicated whenever preventive interventions that require initiation before adulthood are available. ${ }^{43}$ One of the concerns of predictive testing in cancer genetics, especially among children, are potential psychological adverse events.

Currently, the psychological effects of intensive cancer screening in TP53 mutation carriers are not clear. However, results from preliminary studies are encouraging and report psychological benefits from adherence to intensive screening practices in LFS families. ${ }^{44,45}$ The risks and benefits both of revealing and of withholding a clinical or molecular diagnosis of cancer predisposition have been the subject of extensive debate in the literature. ${ }^{46-48}$ Psychological harm may be involved in issues such as increased worry about cancer risk, the need for periodic laboratory and imaging tests and the anxiety that precedes and follows them, and the burden of testing itself. Some studies have found that a passive, pessimistic coping style, low social aspirations, and precarious social support networks also have a negative impact on mutation carriers, as does negative perception of the disease and the risk of cancer itself. ${ }^{49}$ However, during counseling of at-risk children, these psychological vulnerabilities can be identified before any diagnostic or therapeutic measures are taken, thus enabling prevention and mitigation of adverse psychological reactions. ${ }^{50}$

Whenever possible, predictive genetic testing should be performed when the child has a bare minimum of maturity and understanding as to the nature of decision-making and its implications. In other words, as children's intellectual and psychosocial skills mature, they become increasingly capable of communicating and taking part in decisions that affect them. ${ }^{43}$ Most authors believe that predictive genetic counseling and follow-up of minors is justified by the high risk of cancer in LFS/LFL and by the proven benefits of intensive screening..$^{17,42}$ When predictive diagnosis is justified in children who are not mature enough to take part in the decision-making process, the child's parents must be supported throughout the testing process and also later on, when information regarding cancer risk is disclosed to the carrier child or adolescent. The literature has shown that adolescents and young adults usually regard genetic counseling as an opportunity to know the risks of hereditary cancer and support decision-making on aspects such as marrying and having children. ${ }^{51}$ Several studies show that families with LFS/LFL tend to trust and comply with genetic counseling, as they feel safer when educated on the disease and able to understand the diagnosis and better cope with its outcome..$^{43,50}$

\section{Genetic counseling of LFS/LFL and bioethical aspects}

Genetic counseling for hereditary conditions is an educational activity that enables the exchange of information between professionals and patients (and, as necessary, their relatives). When properly informed, patients and their relatives are empowered to make better decisions. ${ }^{52}$ Decision-making capacity is also related to individual psychological and moral development and to issues of voluntariness. The patient's affective relationships and personal system of values and beliefs are key elements in this process. ${ }^{53}$

From the patient's standpoint, at least four factors must be taken into account during genetic counseling: the availability of choices; potential cognitive biases in the presentation of these choices; embedding of a particular decision within a broader moral framework, such as the patient's involvement with other family members; and the patient's own concerns. 3.54

One bioethics issue is at the core of genetic counseling: conflict between the moral duties of warning family members of genetic risk versus the patient's right not to 
know. Once a mutation is identified in a patient, first-degree relatives will have a $50 \%$ chance of also being carriers, and many will be cancer-unaffected at the time of investigation. In current practice, the burden (moral duty) of informing other relatives of this risk, and providing initial information on the possible need for genetic investigation, usually lies with the index case. In this scenario, the repercussions of the patient's unwillingness to know are not restricted to immediate relatives, but may extend to other members of the family as well. ${ }^{55,56}$ Most patients understand they have a duty to inform their relatives themselves, but opinions are divided as to the duty of providers to warn family members if the patient fails to do so. ${ }^{57}$ Other ethically complex scenarios emerge when the index case dies before test results become available, raising repercussions among living relatives ${ }^{58}$ or when patients who are aware of their testing results decide not to share them with the family, or die before they can do so. Ideally, an agreement should be reached before the test as to who may be informed of its results if one of the above situations arises.

Another point of ethical concern, which is particularly common in Brazil, is the performance of genetic testing within a research setting, but for purposes of patient care. Since the publicly-funded Unified Health System does not cover genetic testing for LFS/LFL and other cancer predisposition syndromes, genetic testing under the aegis of a research project is an alternative avenue for access to this information. In this setting, research support is "necessary" to enhance diagnosis. The providers involved in care of these patients must assess the extent to which patients are in a vulnerable situation and which clinical benefits they can derive from research involvement. The relationships between patient care and clinical research, between providers and their patients, between patients and their relatives, and between individual versus group benefits, as well as concerns related to individual and relational privacy, are increasingly the subject of ethical reflections and prompt questions as to how far these issues are taken into account during the provision of genetic counseling and patient care in hereditary breast cancer scenarios.

\section{Conclusion}

Although LFS/LFL is considered a rare disease, affecting approximately 1 in 2.000-5.000 individuals worldwide, it appears to be substantially more common in Southern and Southeastern regions due to a specific TP53 founder mutation (p.R337H), present in 1 in 300 newborns. A recent study conducted in this region of Brazil suggests that $25 \%$ of children diagnosed with tumors of the LFS/
LFL spectrum fulfill criteria for genetic testing for the disease. Pediatricians should be aware of the possibility of LFS/LFL in: (1) children without cancer and with a family history fulfilling LFS/LFL criteria and (2) children with cancer, particularly those with tumors of the LFS/ LFL spectrum. A diagnosis of LFS/LFL have major repercussions for patients and their families, as the pattern of inheritance is well established, confirmatory genetic testing is available. Additionally, interventions designed to reduce the risk of cancers can be prescribed and have shown effectiveness in the early diagnosis of tumors, with significant impact on survival. Ideally diagnosis and genetic counseling for patients and families with suspected LFS/LFL should be undertaken by a multidisciplinary team. Pediatricians, pediatric oncologists and other health care providers involved with the care of children with cancer have a central role in the identification of individuals at high risk for cancer predisposition syndromes.

\section{Authors' contributions}

CR, JG and PAP reviewed all the topics. CBON, PSS, SGS and ALM reviewed the topics' assessment of a suspected case of LFS/LFL, differential diagnosis and genetic counseling and management of families with LFS/LFL. VZO reviewed the topic psychological aspects and JRG reviewed the topic bioethical aspects.

\section{Resumo}

Câncer pediátrico e síndrome de Li-Fraumeni/Li-Fraumeni-like: uma revisão para o pediatra.

Introdução: o câncer é a segunda principal causa de morte em crianças com idades entre 0 e 14 anos, correspondendo a cerca de $3 \%$ de todos os casos diagnosticados no Brasil. Um percentual significativo (5-10\%) dos cânceres pediátricos são associados a síndromes hereditárias para câncer, incluindo Li-Fraumeni/Li-Fraumeni-like síndromes (LFS/LFL), causadas por mutações germinativas no gene TP53. Estudos recentes têm demonstrado que uma mutação específica em TP53, conhecida como p.R337H, está presente em 1 em 300 recém-nascidos no Sul e Sudeste do Brasil. Além disso, um percentual significativo de crianças com tumores do espectro LFS/LFL na região têm uma história familiar compatível com a síndrome. Objetivos: revisão dos aspectos clínicos relevantes da LFS/LFL por equipe multidisciplinar, com foco no câncer pediátrico.

Métodos: o NCBI (PubMed) e SciELO foram consultados, usando as palavras-chave síndrome de Li-Fraumeni, 
síndrome de Li-Fraumeni-like e câncer pediátrico. Todos os artigos publicados entre 1990 e 2014 usando essas palavras-chave foram recuperados e revisados.

Conclusão: apesar de LFS/LFL ser considerada uma doença rara, ela parece ser mais frequente em certas regiões. Reconhecer os critérios e condutas para identificação de pacientes em risco para LFS/LFL é fundamental para o manejo adequado dos pacientes com câncer hereditários e suas famílias. Devido à complexidade dessas síndromes, a abordagem multidisciplinar deve ser realizada. Pediatras e oncologistas pediátricos em áreas com alta prevalência de síndromes hereditárias de câncer têm um papel central no reconhecimento e encaminhamento adequado dos pacientes e famílias para programas de avaliação do risco de câncer genético e de gestão.

Palavras-chave: síndrome de Li-Fraumeni, neoplasias, genes p53, aconselhamento genético, TP53.

\section{References}

1. Little J. Epidemiology of Childhood Cancer. Lyon: IARC Scientific Publications, International Agency for Research on Cancer, 1999.

2. Surveillance, Epidemiology and End Results (SEER) 2012. Available from: http://seer.cancer.gov/publications/childhood/.

3. Parkin DM, Stiller CA, Draper GJ, Bieber CA. The international incidence of childhood cancer. Int J Cancer. 1988; 42(4):511-20.

4. da Silva DB, Pires MMS, Nassar SM. Registro de câncer de base populacional: uma proposta para a apresentação dos dados pediátricos brasileiros. Rev Bras Cancerol. 1997; 43(2):133-7.

5. Ries LAG, Smith MA, Gurney JG, Linet M, Tamra T, Young JL, et al. Cancer incidence and survival among children and adolescents: United States SEER Program 1975-1995 , National Cancer Institute, SEER Program. NIH Pub. No. 99-4649. Bethesda, MD, 1999.

6. Instituto Nacional do Câncer. Estimativa 2012. Incidência do Câncer no Brasil. Available from:http://www.inca.gov.br.

7. Teplick A, Kowalski M, Biegel JA, Nichols KE. Educational paper: screening in cancer predisposition syndromes: guidelines for the general pediatrician. Eur J Pediatr. 2011; 170(3):285-94.

8. Giacomazzi J, Selistre SG, Rossi C, Alemar B, Santos-Silva P, Pereira FS, et al. Li-Fraumeni and Li-Fraumeni-like syndrome among children diagnosed with pediatric cancer in Southern Brazil. Cancer. 2013; 119(24):4341-9.

9. Li FP, Fraumeni JF Jr. Rhabdomyosarcoma in children: epidemiologic study and identification of a familial cancer syndrome. J Natl Cancer Inst. 1969; 43(6):1365-73.

10. Li FP, Fraumeni JF Jr, Mulvihill JJ, Blattner WA, Dreyfus MG, Tucker MA, et al. A cancer family syndrome in twenty-four kindreds. Cancer Res. 1988; 48:(18)5358-62.

11. Nichols KE, Malkin D, Garber JE, Fraumeni JF Jr, Li FP. Germ-line p53 mutations predispose to a wide spectrum of early-onset cancers. Cancer Epidemiol Biomarkers Prev. 2001; 10(2):83-7.

12. Wong P, Verselis SJ, Garber JE, Schneider K, DiGianni L, Stockwell DH, et al. Prevalence of early onset colorectal cancer in 397 patients with classic Li-Fraumeni syndrome. Gastroenterology. 2006; 130(1):73-9.

13. Malkin D, Li FP, Strong LC, Fraumeni JF Jr, Nelson CE, Kim DH, et al. Germ line 53 mutations in a familial syndrome of breast cancer, sarcomas, and other neoplasms. Science. 1990; 250(4985):1233-8.

14. Strong LC, Stine M, Norsted TL. Cancer in survivors of childhood soft tissue sarcoma and their relatives. J Natl Cancer Inst. 1987; 79(6):1213-20.

15. Lustbader ED, Williams WR, Bondy ML, Strom S, Strong LC. Segregation analysis of cancer in families of childhood soft-tissue-sarcoma patients. Am J Hum Genet. 1992; 51(2):344-56.
16. Malkin D. Li-Fraumeni syndrome. Genes Cancer. 2011; 2(4):475-84.

17. Hisada M, Garber JE, Fung CY, Fraumeni JF, Li FP. Multiple primary cancers in families with Li-Fraumeni syndrome. J Natl Cancer Inst. 1998; 90(8):606-11.

18. Trkova M, Hladikova M, Kasal P, Goetz P, Sedlacek Z. Is there anticipation in the age at onset of cancer in families with Li-Fraumeni syndrome? J Hum Genet. 2002; 47(8):381-6.

19. Varley JM. Germline TP53 mutations and Li-Fraumeni syndrome. Hum Mutat. 2003; 21(3):313-20.

20. Wang QE, Zhu Q, Wani MA, Wani G, Chen J, Wani AA. Tumor suppressor p53 dependent recruitment of nucleotide excision repair factors XPC and TFIIH to DNA damage. DNA Repair (Amst). 2003; 2(5):483-99.

21. Cohen RJ, Curtis RE, Inskip PD, Fraumeni JF Jr. The risk of developing second cancers among survivors of childhood soft tissue sarcoma. Cancer. 2005; 103(11):2391-6

22. Lalloo F, Varley J, Ellis D, Moran A, O'Dair L, Pharoah P, et al. Prediction of pathogenic mutations in patients with early-onset breast cancer by family history. Lancet. 2003; 361(9363):1101-2.

23. Garber JE, Offit K. Hereditary cancer predisposition syndromes. J Clin Oncol. 2005; 23:(2)276-92.

24. Palmero EI, Schüler-Faccini L, Caleffi M, Achatz MI, Olivier M, MartelPlanche G, et al. Detection of R337H, a germline TP53 mutation predisposing to multiple cancers, in asymptomatic women participating in a breast cancer screening program in Southern Brazil. Cancer Lett. 2008; 261(1):21-5.

25. Piovezan G. Prevalência do alelo TP53 R337H no Estado do Paraná. [Dissertation]. Curitiba: Universidade Federal do Paraná, 2006.

26. 2Giacomazzi J, Graudenz MS, Osorio CABT, Koehler-Santos P, Palmero EI, Zagonel-Oliveira M, et al. Prevalence of the TP53 p.R337H mutation in breast cancer patients in Brazil. PLoS One. 2014; 9(6):e99893.

27. Giacomazzi J, Koehler-Santos P, Palmero EI, Graudenz MS, Rivero LF, Lima E, et al. A TP53 founder mutation, p.R337H, is associated with phyllodes breast tumors in Brazil. Virchows Arch. 2013; 463(1):17-22.

28. Birch JM, Hartley AL, Tricker KJ, Prosser J, Condie A, Kelsey AM, et al. Prevalence and diversity of constitutional mutations in the p53 gene among 21 Li-Fraumeni families. Cancer Res. 1994; 54(5):1298-1304.

29. Hettmer S, Archer NM, Somers GR, Novokmet A, Wagers AJ, Diller L, et al. Anaplastic rhabdomyosarcoma in TP53 germline mutation carriers. Cancer. 2014; 120(7):1068-75.

30. Eeles RA: Germline mutations in the TP53 gene. Cancer Surv. 1995; 25:101-24

31. Frebourg T, Abel A, Bonaiti-Pellie C, Brugières L, Berthet P, Bressac-de Paillerets $\mathrm{B}$, et al. [Li-Fraumeni syndrome: update, new data and guidelines for clinical management]. Bull Cancer. 2001; 88(6):581-7.

32. Tinat J, Bougeard G, Baert-Desurmont S, Vasseur S, Martin C, Bouvignies E, et al. 2009 version of the Chompret criteria for Li Fraumeni syndrome. J Clin Oncol. 2009; 27(26):e108-9.

33. Lindor NM, McMaster ML, Lindor CJ, Greene MH; National Cancer Institute DoCP, Community Oncology and Prevention Trials Research Group. Concise handbook of familial cancer susceptibility syndromes - second edition. J Natl Cancer Inst Monogr. 2008; (38):1-93.

34. International Agency for Research on Cancer (IARC). IARC TP53 Database. Available from: http://www-p53.iarc.fr.

35. Bougeard G, Sesboüé R, Baert-Desurmont S, Vasseur S, Martin C, Tinat J, et al. Molecular basis of the Li-Fraumeni syndrome: an update from the French LFS families. J Med Genet. 2008; 45(8):535-8.

36. Varley JM, McGown G, Thorncroft M, Santibanez-Koref MF, Kelsey AM, Tricker KJ, et al. Germ-line mutations of TP53 in Li-Fraumeni families: an extended study of 39 families. Cancer Res. 1997; 57(15):3245-52.

37. Petitjean A, Achatz MI, Borresen-Dale AL, Hainaut P, Olivier M. TP53 mutations in human cancers: functional selection and impact on cancer prognosis and outcomes. Oncogene. 2007; 26(15):2157-65.

38. Shlien A, Baskin B, Achatz MI, Stavropoulos DJ, Nichols KE, Hudgins L, et al. A common molecular mechanism underlies two phenotypically distinct 17p13.1 microdeletion syndromes. Am J Hum Genet. 2010; 87(5):631-42.

39. Gonzalez KD, Buzin CH, Noltner KA, Gu D, Li W, Malkin D, et al. High frequency of de novo mutations in Li-Fraumeni syndrome. J Med Genet. 2009; 46(10):689-93.

40. Villani A, Tabori U, Schiffman J, Shlien A, Beyene J, Druker H, et al. Biochemical and imaging surveillance in germline TP53 mutation carriers with Li-Fraumeni syndrome: a prospective observational study. Lancet Oncol. 2011; 12(6):559-67. 
41. Lammens CR, Aaronson NK, Wagner A, Sijmons RH, Ausems MG, Vriends $\mathrm{AH}$, et al. Genetic testing in Li-Fraumeni syndrome: uptake and psychosocial consequences. J Clin Oncol. 2010; 28(18):3008-14.

42. Lammens CR, Bleiker EM, Aaronson NK, Wagner A, Sijmons RH, Ausems MG, et al. Regular surveillance for Li-Fraumeni syndrome: advice, adherence and perceived benefits. Fam Cancer. 2010; 9(4):647-54.

43. McBride KA, Ballinger ML, Killick E, Kirk J, Tattersall MH, Eeles RA, et al. Li-Fraumeni syndrome: cancer risk assessment and clinical management. Nat Rev Clin Oncol. 2014; 11(5):260-71.

44. Dorval M, Patenaude AF, Schneider KA, Kieffer SA, DiGianni L, Kalkbrenner $\mathrm{KJ}$, et al. Anticipated versus actual emotional reactions to disclosure of results of genetic tests for cancer susceptibility: findings from p53 and BRCA1 testing programs. J Clin Oncol. 2000; 18(10):2135-42.

45. Peshkin BN, DeMarco TA, Garber JE, Valdimarsdottir HB, Patenaude AF, Schneider KA, et al. Brief assessment of parents attitudes toward testing minor children for hereditary breast/ovarian cancer genes: development and validation of the Pediatric BRCA1/2 Testing Attitudes Scale (P-TAS). J Pediatr Psychol. 2009; 34(6):627-38.

46. Palmquist AE, Koehly LM, Peterson SK, Shegog M, Vernon SW, Gritz ER. "The cancer bond": exploring the formation of cancer risk perception in families with Lynch syndrome. J Genet Couns. 2010; 19(5):473-86.

47. Gopie JP, Vasen HF, Tibben A. Surveillance for hereditary cancer: Does the benefit outweigh the psychological burden?--A systematic review. Crit Rev Oncol Hematol. 2012; 83(3):329-40.

48. Peterson SK, Pentz RD, Marani SK, Ward PA, Blanco AM, LaRue D, et al. Psychological functioning in persons considering genetic counseling and testing for Li-Fraumeni syndrome. Psychooncology. 2008; 17(8):783-9.
49. Borry P, Evers-Kiebooms G, Cornel MC, Clarke A, Dieickx K; Public and Professional Policy Committee (PPPC) of the European Society of Human Genetics (ESHG). Genetic testing in asymptomatic minors: background considerations towards ESHG Recommendations. Eur J Hum Genet. 2009, 17(6):711-9.

50. Koch L, Svendsen MN. Providing solutions-defining problems: the imperative of disease prevention in genetic counselling. Soc Sci Med. 2005; 60(4):823-32

51. Goldim, JR. Bioética: origens e complexidade. Rev HCPA. 2006; 26(2)86-92.

52. O'Doherty K. Agency and choice in genetic counseling: acknowledging patients concerns. J Genet Couns. 2009; 18(5):464-74.

53. Matsui K, Lie RK, Kita Y, Ueshima H. Ethics of future disclosure of individual risk information in a genetic cohort study: a survey of donor preferences. J Epidemiol. 2008; 18(5):217-24.

54. Kaphingst KA, Janoff JM, Harris LN, Emmons KM. Views of female breast cancer patients who donated biologic samples regarding storage and use of samples for genetic research. Clin Genet. 2006; 69(5):393-8.

55. Kohut K, Manno M, Gallinger S, Esplen MJ. Should healthcare providers have a duty to warn family members of individuals with an HNPCC-causing mutation? A survey of patients from the Ontario Familial Colon Cancer Registry. J Med Genet. 2007; 44(6):404-7.

56. Ormondroyd E, Moynihan C, Watson M, Foster C, Davolls S, Ardern-Jones A, et al. Disclosure of genetics research results after the death of the patient participant: a qualitative study of the impact on relatives. J Genet Couns. 2007; 16(4):527-38.

57. Roshanai AH, Rosenquist R, Lampic C, Nordin K. Does enhanced information at cancer genetic counseling improve counselees knowledge, risk perception, satisfaction and negotiation of information to at-risk relatives?--a randomized study. Acta Oncol. 2009; 48(7):999-1009. 